\begin{tabular}{cc|c|}
\hline \hline \hline & International Journal of Current Research & and Academic Review \\
$f$ & ISSN: 2347-3215 (Online) Volume 6 Number 4 (April-2018) \\
Journal homepage: http://www.ijcrar.com \\
\hline \hline
\end{tabular}

doi: https://doi.org/10.20546/ijcrar.2018.604.002

\title{
Cow's Milk Consumption and the Incidence of Wheezing in Children
}

\author{
Mulya Safri* \\ Department of Child Health Syiah Kuala University, Dr. Zainoel Abidin Hospital, Banda Aceh, Indonesia \\ *Corresponding author
}

\begin{abstract}
Wheezingis the main symptom of asthma in children.One of the predisposing factors is cow's milk consumption. The aim of this study is to identify the association between cow's milk consumption and wheezing incidence in children inBanda Aceh. This is an analytic observational study with cross-sectional design. The sample included 84 children aged 6 months to 5 years were obtained by consecutive sampling. Data collected using questionnaires that included question about cow's milk consumption and ISAAC. The results showed that a statistically significant association between cow's milk consumptionand wheezing incidence in children aged 6 months to 5 years $(p=0.045)$. It is advisable to replace cow's milk with partially or fully hydrolized formula to prevent the occurence of wheezing and malnutrition in children.
\end{abstract}

\section{Article Info}

Accepted: 07 March 2017

Available Online: 20 April 2018

\begin{tabular}{l} 
Keywords \\
\hline Cow's milk, \\
Wheezing, \\
Children aged 6 months to 5 years
\end{tabular}

\section{Introduction}

Asthma is a chronic common lung disease that marked by chronic inflammatory airway obstruction especially in atopic children (Kliegman et al., 2015).

Asthma symptoms are characterized by the appearance of wheezing, coughing, shortness of breath and pain. The most frequent factors that trigger the occurence of asthma in children is smoker parent and food allergy (Killen, 2013).

Food allergy can be caused by more than 170 types of foods.Cow's milk, eggs, seafood and peanut are the most common causes of food allergies in children (Sampson 1993). Cow's milk sensitization frequently occurred in the first 3 years of life and could be characterized as wheezing (Abraham and Ownby 2005; Smith and Ownby 2009).
Previous study showed that children were feeded with formula based on cow's milk have greater risk of suffering from wheezing (Safri et al., 2015). Cow's milk protein stimulates type I and IV hypersensitivity reaction and resulting in chronic inflammatory airway obstruction (O’Brien 2002).

\section{Materials and Methods}

This observational analytic with cross-sectional study was conducted in Pediatric Allergy and Immunology Clinic inBanda Aceh, the capital of Aceh Provence, from September to December 2017. A total of 84 children aged 6 months to 5 years were collected by consecutive sampling. Children feeded with formula based on cow's milk or partial/fully hydrolyzed formulawere included into inclusion criteria. Children suffering from other lung diseases, congenital problem, smoker parent, have pets, sputum retention and bronchiolitis were excluded in this 
study.Data collected from questionnaires completed by parents and ISAAC question. Chi-square test were performed to analyze the obtained data. Data collected included age, sex, nutritional status, history of wheezing, allergy risk and history of previous treatment. All analyses were performed with SPSS ver. 22.0 (IBM SPSS Statistics for Windows, Ver 22.0. Armonk, NY, USA). Test results revealed statistically significant if $P$ value of $<0.05$.

\section{Results and Discussion}

We obtained 84 children that fulfilled the inclusion criteria. Subject characteristics are shown in Table 1. Male subject have slightly different numbers than female subject, 41 (48.4\%) vs 43 (51.2\%), respectively. Most of the subject aged between 4 to 5 years old $(36.9 \%)$.

More than half of the study subject has a normoweight nutritional status (52.4\%). Around 54 (64.3\%) children suffering from wheezing. Although 48 (57.2\%) children were feeded with formula based on cow' milk, but the amount of children that were feeded with partial/fully hydrolyzed formulaalso reached $42.8 \%$. Furthermore, 63 (75) chidren were categorized into low-moderate allergy risk. We analyzed the relation between variables in Table 2. From a total 54 children suffering from wheezing, around 42 children were feeded with formula based on cow's milk. The results showed statistically significant difference between variables $(P=0.000)$. We also analyzed the correlation between wheezing and allergy risk in the family. But there was no statistically significant difference between variables $(P=0.430)$.

Wheezing incidence especially in atopic children is associated with many factors such as smoker parent, allergy risk, consumption of food containing allergens especially cow's milk (Safri et al., 2015). In our study, $64.3 \%$ of children aged less than 5 years suffered from wheezing. Wheezing incident are often occurs at an early age. Several studies have shown that symptom usually appear within first year of life and will disappear as the child getting older (Safri and Putra, 2015). Previous study in Michigan also mentioned that the incidence of wheezing most commonly occurs in the first 2 years of life that is amount to $27.2 \%$ (Wegienka et al., 2009).

Table.1 Subject characteristics

\begin{tabular}{lcc}
\hline Variable & N (84) & \% \\
\hline Gender & 41 & 48.8 \\
Male & 43 & 51.2 \\
Female & & \\
Age & 14 & 16.7 \\
6 months to 2 years & 22 & 26.2 \\
2 to 3 years & 17 & 20.2 \\
3 to 4 years & 31 & 36.9 \\
4 to 5 years & & \\
Nutritional status & 23 & 27.4 \\
Underweight & 44 & 52.4 \\
Normoweight & 9 & 10.7 \\
Overweight & 8 & 9.5 \\
Obesity & & \\
Wheezing & 54 & 64.3 \\
Yes & 30 & 35.7 \\
No & & \\
Feeding history & 36 & 42.8 \\
Partial/fully hydrolyzed & 48 & 57.2 \\
Cow's milk & & \\
Allergy Risk & 63 & 75 \\
Low-moderate & 21 & 25 \\
High & & \\
\hline
\end{tabular}


Table.2 Bivariate analyzed between variables

\begin{tabular}{lccc}
\hline \multirow{2}{*}{ Variable } & \multicolumn{2}{c}{ Wheezing } & \multirow{2}{*}{$P$} \\
\cline { 2 - 3 } Feeding history & $12(33.3)$ & $24(66.7)$ & 0.000 \\
Partial/fully hydrolyzed & $42(87.5)$ & $6(12.5)$ & \\
Cow's milk & & & \\
Allergy risk & $39(61.9)$ & $24(38.1)$ & 0.430 \\
Low-moderate & $15(71.4)$ & $6(28.6)$ & \\
High & & \\
\hline
\end{tabular}

Cow's milk allergy is knows as one of the most common triggers of wheezing in children. In this study, we found $87.5 \%$ children that were feeded with formula based on cow's milk experiencing wheezing in their life. This results is in line with previous study that also found the same thing (Sheriff et al., 2001; Lopez et al., 2002). Cow's milk protein stimulates type I and IV hypersensitivity reaction and resulting in chronic inflammatory airway obstruction (O'Brien 2002). Increasing production of immunoglobulin $\mathrm{E}(\mathrm{IgE})$ and interleukin (IL)-4, IL-5, and IL-10 were found in children who experienced hypersesitivity reactions triggered by cow's milk protein (Safri et al., 2015; Hǿst and Halken, 2003).

Cow's milk consists 3 grams of protein per $100 \mathrm{ml}$ and included 25 different proteins which may act as antigens.The most common antigens in cow's milk arecasein and whey protein. Wheyconsists of $\beta$ lactoglobulin, $\quad \alpha$-lactalbumin, bovine serum albuminandbovin gamaglobulin which is an allergypromoting protein (Martorell-Aragonés et al., 2015; Siregar, 2001).

Studies suggest that partially or fully hydrolyzed formula are highly recommended to be given to atopic children in the first 5 years of life. This formula will inhibit the occurence of hypersensitivity reactions due to cow's milk protein (Alexander et al., 2010; Caffarelli et al., 2010). Our study showed that $66.7 \%$ of children who were received partially/fully hydrolyzed formula did not suffer from wheezing.

Allergy risk also related with the occurence of wheezing in children. Allergy symptoms were found in $40 \%$ children with a family history of atopy, although $10 \%$ of children who do not have a history of atopy may also experience allergic symptoms (Johansson et al., 2004). Previous study obtained obtaineda correlation between the allergy risk and the occurence of wheezing, in which infants witha high risk of allergy were more common sufferedfrom wheezing (Safri et al., 2015). Furthermore, children with a history of atopy have 2 times greater risk to suffer from wheezing (Balemans et al., 2006). In contrast of our study, we found no statistically significant difference between allergy risk and wheezing in children. Further research is suggested to see more correlation between these factors.

Cow's milk allergy is also often associated with the incidence of malnutrition in children. This is because children with a history of allergy have impaired nutritional absorption due to bowel inflammation (Seppo et al., 2005). This is in line with our study that also found $27.4 \%$ of children suffering malnutrition, but we did not conduct any further analysis on that issue.

In conclusion, cow's milk consumption increased the incidence of wheezing in children aged less than 5 years. This type of milk also associated with the incidence of malnutrition in children. It is advisable to replace cow's milk with partially or fully hydrolized formula to prevent the occurence of wheezing and malnutrition in children.

\section{References}

Abraham CM, Ownby DR. Ontogeny of the allergic inflammatory response. In: [Immunology and allergy clinics of North America]. Moss MH (ed). Philadelphia: Saunders Elsevier 2005; p. 215-29.

Alexander DD, Schmitt DF, Tran NL, Barraj LM, Cushing CA. Partially hydrolyzed $100 \%$ whey protein infant formula and atopic dermatitis risk reduction: a systematic review of the literature. Nutr Rev. 2010; 68: 232-45.

Balemans WA, van der Ent CK, Schilder AG, Sanders AM, Zielhuis GA, Rovers MM. Prediction of asthma in young adults using childhood characteristics: development of a prediction rule. $\mathbf{J}$ Clin Epidemiol 2006; 59: 1207-12.

Caffarelli C, Baldi F, Bendandi B, Calzone L, Marani M, Pasquinelli P. Cow's milk protein allergy in 
children: apractical guide. Ital J Pediatr. 2010; 36: 15.

Hǿst A, Halken S. Approach to feeding problems in the infant and young child. In: [Pediatric allergy: principles and practice. 7th ed]. Leung DY, Sampson HA, Geha RS, Szefler SJ (eds). Missouri: Mosby 2003; p. 488-94.

Johansson SG, Bieber T, Dahl R, Friedmann PS, Lanier $\mathrm{BQ}$, Lockey RC, et al., Revised nomenclature for allergy for global use: report of the nomenclature review comittee of the world allergy organization. $\mathbf{J}$ Allergy Clin Immunol 2004; 11: 38-83.

Killeen K. Pathophysiology, Diagnosis, and Clinical Assesment of Asthma in Adult. Nurs Clin North Am 2013; 48: 11-23.

Kliegman, Robert M, Bonita F. Stanton. Joseph W., Nina F. Schor REB. Childhood Asthma. In: Gatsch M, editor. Nelson Textbook of Pediatrics. 20th ed. Philadephia: Elsevier Inc.; 2015. p. 1095-115.

Lopez N, Barros-Mazon S, Vilela MM, Neto AC, Ribeiro JD. Are immunoglobulin E levels associated with early wheezing? A prospective study in Brazilian infants. Eur Respir J 2002; 20: 640-5.

Martorell-Aragonés A, Echeverría-Zudaire L, AlonsoLebrero E, Boné-Calvo J, Martín-Muñoz MF, Nevot-Falcó S, et al., Position document: IgEmediated cow's milk allergy. Allergo et Immunol 2015; 43(5): 507-26.

O'Brien RM. Skin prick testing and in vitro assays for allergic sensitivity. Austr Pres 2002; 25: 91-3.

Safri M, Lubis B, Munasir Z, Mulyadi M, Mudatsir M, Putra AR. Cow's milk protein sensitization on the lymphocyte Th-1 and Th-2 activity in relation to wheezing in the first year of life. Hum Vet Med 2015; 7(1): 31-7.

Safri M, Putra AR. Early allergy symptoms in infants aged $0-6$ months on breast milk subtitutes. Pediatr Indones 2015; 55: 18-22.

Sampson HA. Adverse reactions to foods. In: [Allergy, principle and practice. 4th ed]. Middleton E, Reed CE, Elliot EF, Adkinson NF, Yunginger JW, Busse WW (eds). St.Louis: Mosby 1993; p. 1661-86.

Seppo L, Korpela R, Lönnerdal B, Metsäniitty L, Juntunen-Backman K, Klemola T, et al., A followup study of nutrient intake, nutritional status, and growth in infants with cow milk allergy fed either a soy formula or an extensively hydrolyzed whey formula. Am J Clin Nutr. 2005; 82: 140-5.

Sheriff A, Peters TJ, Henderson J, Strachan D. Risk factor associations with wheezing patterns in children followed longitudinally from birth to $31 / 2$ years. Inter J Epidem 2001; 30: 1473-84.

Siregar SP. Food Allergies in Infants and Children. Sari Pediatr. 2001; 3: 168-74.

Smith HP, Ownby DR. Clinical significance of immunoglobin E. In: [Middleton's allergy: principles and practice. 7th ed]. Adkinson NF, Bochner BS, Busse WW, Holgate ST, Lemanske RF, Simons FE (eds). Missouri: Mosby 2009. p. 845-57.

Wegienka G, Havstad S, Zoratti EM, Ownby DR, Johnson CC. Association of early life wheeze and lung function. Ann Allergy Asthma Immunol 2009; 102(1): 29-34.

\section{How to cite this article:}

Mulya Safri. 2018. Cow's Milk Consumption and the Incidence of Wheezing in Children. Int.J.Curr.Res.Aca.Rev. 6(4), 11-14. doi: https://doi.org/10.20546/ijcrar.2018.604.002 